\title{
The Role of Estrogen Receptors in Proliferation of Non-Small Cell Lung Cancer
}

\author{
Nan Yư ${ }^{1 *}$, Yongjun $\mathrm{Jia}^{2}$, Yong Yu${ }^{1}$, Lei Deng ${ }^{3}$, Cong Shen ${ }^{3}$, You-min Guo ${ }^{3}$ and Haifeng Duan ${ }^{1}$ \\ ${ }^{1}$ Department of Radiology, The Affiliated Hospital of Shaanxi University of Traditional Chinese Medicine, Xian Yang, P.R China \\ ${ }^{2}$ Department of Medical Imaging, Yanan University Affiliated Hospital, Yanan, P.R China \\ ${ }^{3}$ Department of Radiology, The First Affiliated Hospital of Xi'an Jiaotong University, Xi'an, P.R China
}

\begin{abstract}
To explore the expression pattern of ERs in NSCLC tissues and assess their relationship with tumor histopathological variable. In our study, Ers expression was examined using Real-time PCR with specimens of 28 NSCLC patients. It was shown that both ERa and Er $\beta$ were over expression in NSCLC tissues, and also the Mrna concentration of both $\mathrm{ERa}$ and $\operatorname{Er} \beta$ were significantly higher in primary tumor T2 stage than in $\mathrm{T} 1$ stage and higher in squamous carcinoma than in adenocarcinoma. However, the activation of $E R a$ and $\operatorname{Er} \beta$ were completely different. To further explore the role of Ers in development and progression of NSCLC, we used Ers selective siRNA or antagonist in vitro experiments. The results showed that $\operatorname{Er} \beta$ but not ERa can mediate E2 induced cell growth, since siRNA targeting Er $\beta$ but not ERa gene can induce cell cycle arrest at $\mathrm{G} 1$ phase by down regulation of cyclinD1 expression, and also cell cycle regulators $\mathrm{p} 21^{\text {Waf } / / \mathrm{Cip} 1}$ and $\mathrm{p} 53$ were involved in this signaling pathway.
\end{abstract}

Keywords: Estrogen receptors; Non-small cell lung cancer; siRNA; P53; Proliferation

\section{Introduction}

Estrogens and its receptors are key signaling molecules that regulate various physiological processes, such as cell growth, development, and differentiation $[1,2]$. Ers are also involved in the development of many types of malignant tumors, including breast and gynecologic cancers [3-6], endocrine gland cancers [7-15], digestive cancers [16-18] and lung cancer [19-22]. Estrogens exert their biological effect through two classical estrogen receptors(Ers) subtypes, $\mathrm{ERa}$ and $\operatorname{Er} \beta$, and novel estrogen receptor G protein coupled receptor 30 (GPR30) [23].

Lung cancer, especially Non-small cell lung cancer (NSCLC) is the leading cause of cancer-related mortality for both men and women worldwide. Estrogen signaling pathways may play an important role in development of lung cancer. The cellular response to estrogen is mainly mediated by ERa and $\operatorname{Er} \beta$. There was increasing evidence to show that NSCLC express both ERa and $\operatorname{Er} \beta$ in nucleus as well as extra-nuclear sites [19]. It was observed that $\operatorname{Er} \beta$ but not ERa is the dominant form in normal lung cancer cell line and tissues, and loss of $\operatorname{Er} \beta$ leading to abnormal lung structure and systemic hypoxia [24,25]. Moreover, when expression of either ERa or $\operatorname{Er} \beta$ was suppressed by small interfering RNA (siRNA), the proliferation of NSCLC cells were significantly reduced [20], and also, blockage of Ers by Ers antagonist ICI 182780 lead to the inhibition of NSCLC cell line growth [26]. Therefore, the function of ERa and $\operatorname{Er} \beta$ seems to prompt the cell proliferation since block of both of them lead to arrest of tumor growth. However, the role of ERa and $\operatorname{Er} \beta$ are complicated by found that Era positive and $\operatorname{Er} \beta$ negative lung cancer patients are associated with poor prognosis [21], and absence of $\operatorname{Er} \beta$ expression is a marker showing high risk of lung cancer patients even an early clinical stage [21]. While some study found that Era was elevated in tumor but was not predictive of survival [27]. Although these studies reveal the importance of estrogen receptors in promoting the growth of lung cancers, but it is not clear which ER subtype is involved.

In our study, we explored the expression pattern of Ers in NSCLC tissues, and also the relationship between Ers expression with the tumor histological subtype, pathological stage and histological stage of NSCLC. To elucidate the role of ERa and Er $\beta$ in NSCLC cell lines were chosen.

\section{Materials and Methods}

\section{Patients}

Lung cancer tissues and normal tissues from 28 patients with NSCLC were collected during primary debulking surgery from January 2009 to January 2011. The patients were selected according to the following criteria: (a) primary none small cell lung cancer; (b) previously untreated; (c) complete patient characteristics information; and (d) surgery as the first treatment.

The patient information was recorded as follows: clinical diagnosis, pathological stage, histologic subtype and histologic grade. The tissues were classified into two groups; one is lung tumor tissues group; and the other is corresponding tumor-free lung tissues from the same patient. All the tissues were obtained according to protocol of lung cancer patients during surgery to remove the tumors. Tissues were frozen immediately in liquid nitrogen and kept at -80a. Patient characteristics are summarized in Table 1.

\section{Cell culture and transfection}

NSCLC cell line, H1650 and A549 (ATCC, USA), were cultured in

*Corresponding authors: Nan Yu, Department of Radiology, The Affiliated Hospital of Shaanxi University of Traditional Chinese Medicine, Weiyang Western Road, Xian Yang, 712000, P.R China, Tel: 86-029-33320881; Fax: 86029-33320881; E-mail: yunan0512@sina.com

Received February 02, 2018; Accepted March 15, 2018; Published March 20, 2018

Citation: Yu N, Jia Y, Yu Y, Deng L, Shen C, et al. (2018) The Role of Estrogen Receptors in Proliferation of Non-Small Cell Lung Cancer. J Cancer Sci Ther 10 045-051. doi:10.4172/1948-5956.1000516

Copyright: ( 2018 Yu N, et al. This is an open-access article distributed under the terms of the Creative Commons Attribution License, which permits unrestricted use, distribution, and reproduction in any medium, provided the original author and source are credited. 
Citation: Yu N, Jia Y, Yu Y, Deng L, Shen C, et al. (2018) The Role of Estrogen Receptors in Proliferation of Non-Small Cell Lung Cancer. J Cancer Sci Ther 10: 045-051. doi:10.4172/1948-5956.1000516

RPMI medium 1640 (ATCC, USA) supplemented with 10\% fetal calf serum (ATCC, USA) at $37^{\circ} \mathrm{C}$ under $5 \%$ humidified $\mathrm{CO}_{2}$ and $100 \mu \mathrm{g} / \mathrm{ml}$ each of streptomycin and penicillin G (GIBCO, USA). The anti-ERa, anti-ER $\beta$ and anti-GPR30 siRNA (Santa cruz, USA) were transfected by Lipofectamine ${ }^{\text {tax }}$ RNAiMAX (Invitrogen, USA) according to the manufacturer's instructions. Briefly, approximately $2 \times 10^{4}$ cells/ well were grown overnight in 24-wells plate. When the cells reached $80 \%$ confluence, they were transfected with anti-ERa siRNA $(30 \mathrm{nM})$, anti-ER $\beta$ siRNA (30 $\mathrm{nM})$ or anti-GPR30 siRNA (30 nM) and negative control siRNA (30 nM) separately in anti-body free medium using lipofectamine $\mathrm{e}^{\mathrm{m} x}$ RNAiMAX. After incubation for $48 \mathrm{~h}$ at $37^{\circ} \mathrm{C} 200 \mu \mathrm{l}$ RPMI 1640 with $10 \%$ FBS was added and then subjected to real-time RT-PCR and western blot analysis.

\section{RNA extraction and reverse transcription}

Lung tumor tissue $(\mathrm{N}=28)$ and the corresponding tumor-free tissue $(\mathrm{N}=28)$ were homogenized and total RNA extraction from tissues was performed using RNeasy Mini Kit (Qiagen, Valencia, CA). RNA quality was checked with Spectrophotometer (NanoDrop 1000). Almost all samples had high-quality RNA. $1 \mu \mathrm{g}$ RNA was reverse transcribed into cDNA with Omniscript RT kit (QIAGEN, Germany) according to the manufacturer's protocol.

\section{Quantitative real-time PCR}

Primers (IDT, USA) for estrogen receptors and other genes were designed to locate into two exons, Sequences of the primers used in the Real-Time PCR analysis were shown in Table 2. The 18s gene was chosen as an endogenous house-keeping control gene. Quantitative real-time PCR was performed using Cyler iQ Real-time PCR Detection System (BIO RAD iQ5 Optical Module. Reaction mixtures contained 1 $\times$ SYBR Green PCR supermix (Bio-rad, USA), $0.1 \mu \mathrm{l}$ Primer, $1 \mu \mathrm{l}$ cDNA template in total volume of $25 \mu \mathrm{l}$. Thermal cycling conditions included activation at $95^{\circ} \mathrm{C}(10 \mathrm{~min})$ followed by 40 cycles each of denaturation at $95^{\circ} \mathrm{C}(15 \mathrm{sec})$ and annealing at $60^{\circ} \mathrm{C}(1 \mathrm{~min})$.

Each reaction was performed in triplicate and negative controls were included in each experiment. To compare the expression levels among different samples, the relative mRNA levels were calculated using the comparative delta $\mathrm{CT}(\Delta \mathrm{Ct})$ method.

\section{Western blot analysis}

After transfection, cells were lysed in lysis buffer. Equivalent amounts of protein lysates from each sample were separated by

\begin{tabular}{|c|c|}
\hline Patient characteristics & $\mathrm{N}=\mathbf{2 8}$ \\
\hline \multicolumn{2}{|l|}{ Age } \\
\hline Mean & 63 \\
\hline Range & $43-71$ \\
\hline \multicolumn{2}{|l|}{ Pathological stage } \\
\hline T1, N0, M0 & $N=11$ \\
\hline T2, N0, M0 & $\mathrm{N}=17$ \\
\hline \multicolumn{2}{|l|}{ Histologic grade } \\
\hline G1 Well differentiated (Low grade) & $\mathrm{N}=2$ \\
\hline G2 Moderately differentiated (intermediated grade) & $\mathrm{N}=14$ \\
\hline G3 Poorly differentiated (High grade) & $\mathrm{N}=12$ \\
\hline \multicolumn{2}{|l|}{ Histologic subtype } \\
\hline Adenocarcinoma & $\mathrm{N}=16$ \\
\hline Squamous cell lung carcinoma & $N=10$ \\
\hline Large Cell Carcinoma & $\mathrm{N}=1$ \\
\hline Adeno-squamous cell carcinoma & $N=1$ \\
\hline
\end{tabular}

Table 1: Patient characteristics.
Table 2: Sequences of the primers used in the real-Time PCR analysis.

\begin{tabular}{|c|c|}
\hline RNAs & Primer sequences \\
\hline \multirow{2}{*}{$\begin{array}{l}\text { Human estrogen receptor a } \\
\text { mRNA }\end{array}$} & 5'-GGAGACGGACCAAAGCCACT-3' \\
\hline & 5'-TTCCCAACAGAAGACAGAAGATG-3' \\
\hline \multirow{2}{*}{$\begin{array}{l}\text { Human estrogen receptor } \beta \\
\text { mRNA }\end{array}$} & 5'-CACGTCAGGCATGCGAGTAAC-3' \\
\hline & 5'-ACCCCGTGATGGAGGACTTG-3' \\
\hline \multirow{2}{*}{ Human GPR30 mRNA } & 5'-ACGAGACTGTGAAATCCGCAACCA-3' \\
\hline & 5'-ATCAGGCTGGAGGTGCACTTGGAA-3' \\
\hline \multirow{2}{*}{ Human cyclin A2 mRNA } & 5'-CCTGCA AACTGCAAAGTTGA-3' \\
\hline & 5'-AAAGGCAGCTCCAGCAATAA-3' \\
\hline \multirow{2}{*}{ Human cyclin D1 mRNA } & 5`- CAGGCGGCTCTTTTTCAC-3` \\
\hline & 5`-CCCTCGGTGTCCTACTTCAA-3` \\
\hline \multirow{2}{*}{ Human P53 mRNA } & 5'-TGACTGTACCACCATCCACTA-3’ \\
\hline & 5'-AAACACGCACCTCAAAGC-3’ \\
\hline \multirow{2}{*}{ Human P21 mRNA } & 5'-TGGACCTGTCACTGTCTTGT-3' \\
\hline & 5'-TCCTGTGGGCGGATTAG-3' \\
\hline \multirow{2}{*}{ 18s rRNA } & 5'-GGGAGGTAGTGACGAAAAATAACAAT-3' \\
\hline & 5'-CССTCCAATGGATCCTCGTTAAAGGA-3' \\
\hline
\end{tabular}

electrophoresis through pre-cast $10 \%$ Tris-HCL polyacrylamide gel and transferred to PVDF membranes. Nonspecific binding site were block by incubation in 1X PBS. Primary antibodies (Santa cruz, USA) were incubated with the membranes and recognized with secondary antibodies (Santa cruz, USA). ECL-Plus Western Blotting Detection Reagents (Amersham Biosciences, Piscataway, NJ, USA) were used to visualize the complexes.

\section{Cell viability analysis}

Cells were seeded in phenol red-free RPMI 1640 medium supplemented with $10 \%$ 4X dextran-coated, charcoal-treated FBS (SFS) in 24-well plates or 96-well plates. After overnight attachment, the cell culture medium was removed. The adherent cell was washed twice with sterile PBS, and the cells were then treated with the indicated ligands for a total of $48 \mathrm{~h}$. Selective siRNA or antagonist treatment were $1 \mathrm{~h}$ before E2. The effect of treatment on cell growth was determined by MTT assay. The MTT assay kits were purchased from ATCC, and assays were according to the manufacturer's protocol. The percentage of cell viability was calculated using a standard curve and normalized to non-treated control.

\section{Flow cytometric analysis}

Cells were cultured overnight in RPMI-1640 medium and then treated with siRNA of ERa and ER $\beta$ for $48 \mathrm{~h}$. The treated cells were fixed and stained with propidium iodide (Sigma USA). At least $1 \times 10^{6}$ stained cells were analyzed using FACSAAria (BD Biosciences USA).

\section{Statistical analysis}

All data shown as bar graphs are expressed as the mean \pm SE. The statistical significance of differences was calculated by one-way ANOVA and two-tailed $t$ test analysis. The correlation between gene expressions was evaluated by chi-square test. Two-tailed $\mathrm{P}<0.05$ was considered to be statistically significant.

\section{Results}

\section{Both ERa and ER $\beta$ mRNA were over-expression in NSCLC tissues}

We examined the expression of ERs in all lung tumor tissues and the corresponding tumor-free lung tissues from same patient. Both the ERa and ER $\beta$ mRNA transcript expression levels were over-expression in NSCLC tissues Table 3. However, GPR30 mRNA transcript showed 
Citation: Yu N, Jia Y, Yu Y, Deng L, Shen C, et al. (2018) The Role of Estrogen Receptors in Proliferation of Non-Small Cell Lung Cancer. J Cancer Sci Ther 10: 045-051. doi:10.4172/1948-5956.1000516

\begin{tabular}{|c|c|c|}
\hline Variables & ERa mRNA & ER $\beta$ mRNA \\
\hline Normal $(n=28)$ & $1.01 \pm 0.03$ & $1.02 \pm 0.03$ \\
\hline Cancer $(n=28)$ & $5.17 \pm 0.07$ & $4.08 \pm 0.05$ \\
\hline P value & $0.004^{*}$ & $0.002^{*}$ \\
\hline & Pathological stage \\
\hline T1, N0, M0 $(n=11)$ & $1.93 \pm 0.23$ & $1.62 \pm 0.12$ \\
\hline T2, N0, M0 $(n=17)$ & $6.02 \pm 0.50$ & $5.07 \pm 0.52$ \\
\hline P value & $0.009^{*}$ & $0.019^{*}$ \\
\hline \multicolumn{3}{|c|}{ Histologic subtype } \\
\hline Adenocarcinoma(n=16) & $4.09 \pm 0.52$ & $2.62 \pm 0.62$ \\
\hline Squamous $(n=10)$ & $7.64 \pm 0.97$ & $5.82 \pm 0.26$ \\
\hline P value & $0.03^{*}$ & $0.05^{*}$ \\
\hline * Difference is significantly at 0.05 level \\
\hline
\end{tabular}

Table 3: ERa and ERß mRNA concentration in patients with NSCLC.

a lower-expression in NSCLC tissues. It was also shown the ERa and ER $\beta$ mRNA concentrations according to pathological stage. Significant increasing of ERa and ER $\beta$ mRNA concentration in T2 stage compared with T1 stage in NSCLC patients were found. Additionally, as shown in Table 3. ERa and ER $\beta$ mRNA concentrations were different according to the tumor histologic subtype by finding that squamous carcinoma has higher mRNA concentration than adenocarcinoma in both ERa and ER $\beta$ expression. However, there is no correlation between ERs mRNA concentration and histologic tumor grade.

\section{ER $\beta$ but not ERa mediates estrogen-dependent growth of NSCLC}

To evaluate the role of ERa and ER $\beta$ in non-small cell lung cancer, we used receptor selective siRNA to down regulate the ERa, ER $\beta$ and GPR30 expression separately in H1650 cell lines, as well as A549 cell lines. and then Real-time RT-PCR and western blotting were performed to determine ERa, ER $\beta$ and GPR30 expression levels in transfected NSCLC cell lines (Figure 1). When H1650 cell line were transfected with anti-ERa siRNA, anti-ER $\beta$ siRNA or anti-GPR30 siRNA, the mRNA concentration (Figure 1) and proteins level (Figure 2) were down-regulated. The results obtained from A549 cells were same.

To determine whether the expression of ERa or ER $\beta$ affect the NSCLC cells proliferation, Cell viability was detected using MTT method. The cell growth in $10 \mathrm{nM} \mathrm{E} 2$ treatment group had no significant difference from that in control group. However, blocking of estrogen receptors before $\mathrm{E} 2$ treatment significantly decreased the proliferation of cells compared with that in E2-treatment group. Furthermore, the role of ER $\beta$ was detected by blocking both ERa and GPR30 expression by selective siRNA but left ER $\beta$ expression, and the result shown that the cell growth was increased compared with all ERs blockage group. However, no difference was found in ER $\beta$ and GPR30 blockage but ERa expression group compared with all ERs blockage group (Figure $3 \mathrm{~A})$. It indicated that up-expression and down-expression of ER $\beta$ but not ERa can accelerate and inhibit the cellular proliferation.

To further confirm that ER $\beta$ but not ERa is involved in NSCLC cells proliferation, we performed cell proliferation assays with ERa-, ER $\beta$ and GPR30 selective antagonist. Combined with G15 and MPP, but not PHTPP can stimulate the growth of H1650 cells, while combined with PHTPP and G15 shows no difference (Figure 3B)

\section{Inhibition of ER $\beta$ induced a G1-phase cell-cycle arrest}

Flow cytometric analysis (Figures 4A-4D) showed a significant increase in the number of cells in G0/G1 phase after treatment of H1650 with anti-ER $\beta$ siRNA for $48 \mathrm{hr}$, as compared with that in control cells. It indicated that the induction of a cell cycle arrest at G1 phase was induced by ER $\beta$ siRNA in H1650 cells. Further, the role of ERo was further determined by transfection with ERa siRNA, and the result showed no significantly difference in G0/G1 cell population compared with control group.

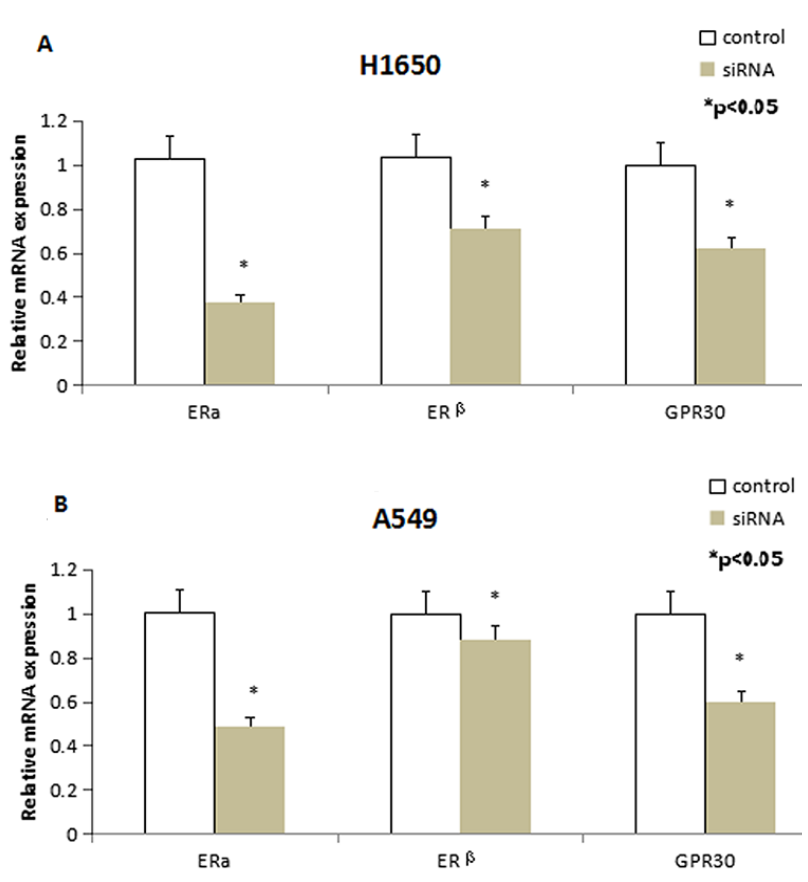

Figure 1: mRNA Expression of ERs are reduced by anti-ER siRNA Transfection: As determined by real-time PCR, mRNA expression of ERa, ER $\beta$ and GPR30 are reduced by anti-ERs siRNA transfection. ${ }^{*} \mathrm{P}<0.05$ vs control.

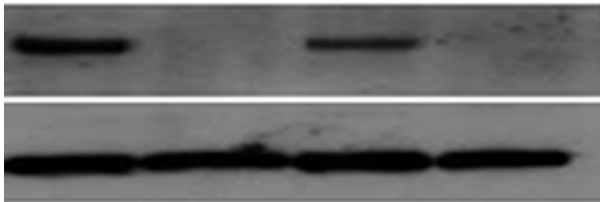

ER a

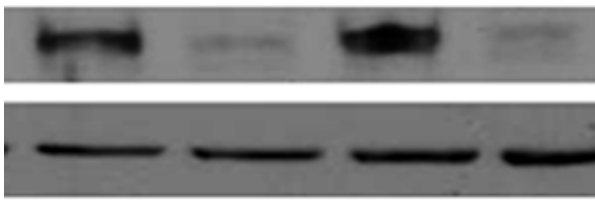

B-actin

ER $\beta$

$\beta$-actin

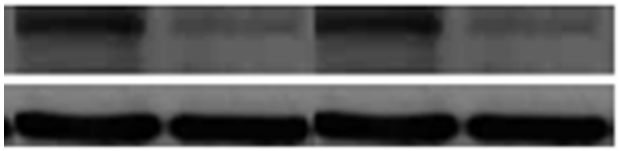

GPR30

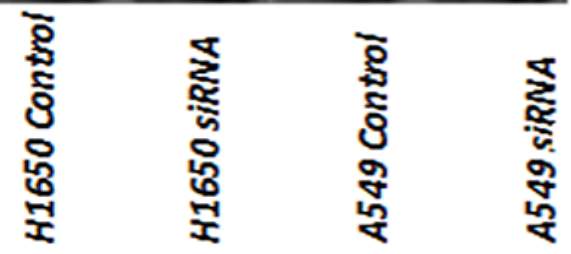

B-actin

Figure 2: Protein expression of ERs were reduced by anti-ER siRNA Transfection: Transfection with siRNA specially reduced ERs protein expression compared with control. 

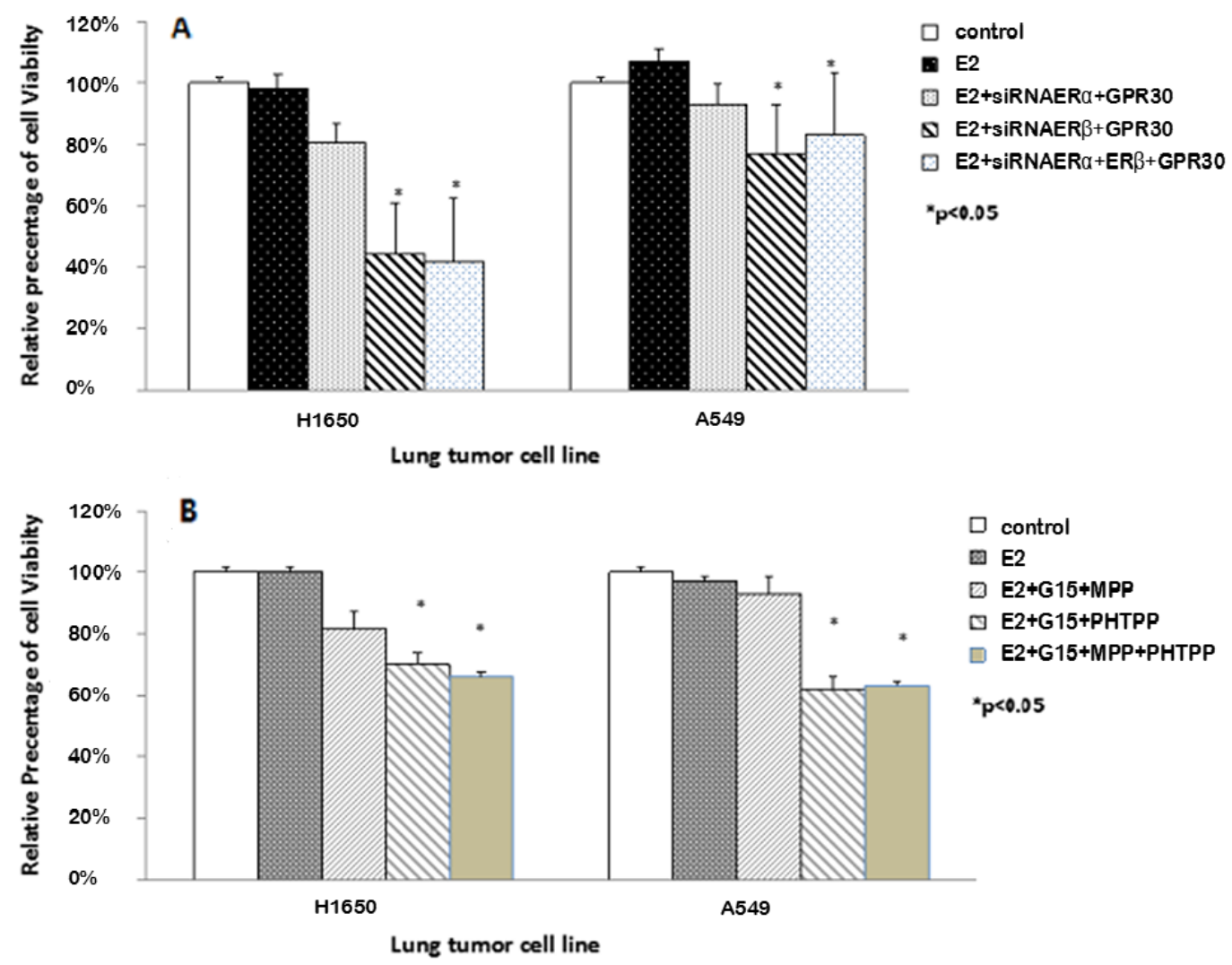

Figure 3: ERßis Associated with Cell Growth induced by Estrogen: A: The inhibitory of ERs by siRNA before E2 treatment decrease the cell growth significantly $\left({ }^{*} \mathrm{p}<0.05\right.$ vs control). Pre-treatment with ERa siRNA and GPR30 siRNA transfection followed by $10 \mathrm{nM}$ E2 increase the growth of cells significantly compared with E2+ GPR30 siRNA+ERa siRNA+ERß siRNA (** $P<0.05$ vs $E 2+G P R 30$ siRNA+ERa siRNA+ERß siRNA). B: Also, treatment cells with ERs selective antagonist (1 $\mu M$ MPP, PHTPP and G15) can significantly reduce cell growth ( ${ }^{*} p<0.05$ vs control), and inhibitory of ERa and GPR30 by MPP and G15 can increase the cell relative viability $\left({ }^{* *} p<0.05\right.$ vs $\left.E 2+G 15+M P P+P H T P P\right)$. So it shows that $E 2$ induced $H 1650$ cell proliferation through $E R \beta$-mediated signaling.

A
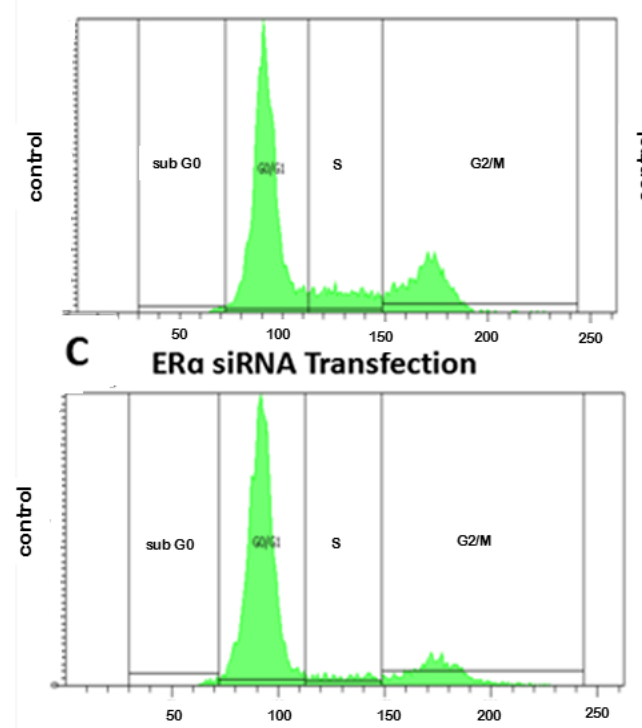

B
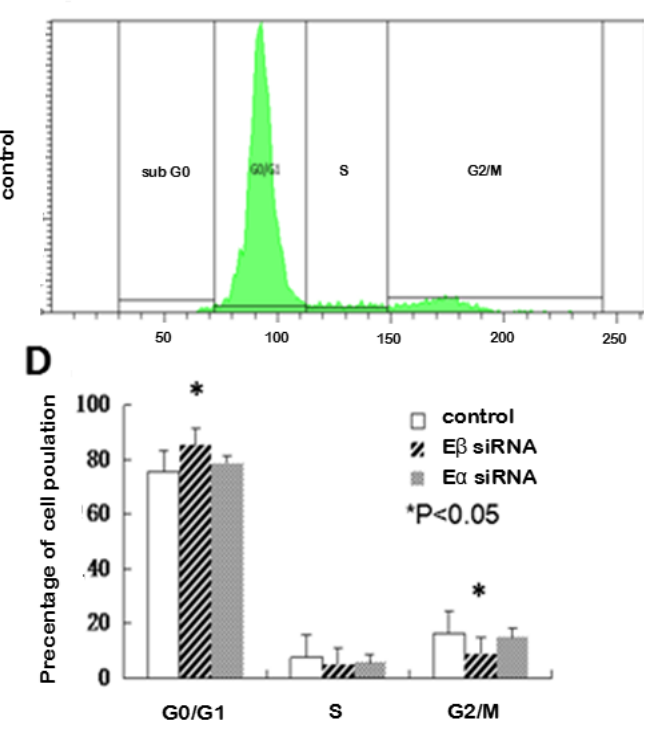

Figure 4: Cell cycle distrubution of $\mathrm{H} 1650$ Transfected with ERa or ER $\beta$ for $48 \mathrm{~h}$ : inhibitory of ER $\beta$ expression by siRNA induced cell cycle arrest at G1 phase, while the cell cycle distribution of cells transfected with ERa siRNA showed no difference compared with control, * $p<0.05 \mathrm{VS}$ control. 
To determine whether the anti-ER $\beta$ siRNA treated H1650 were arrested at the G0/G1 phase; we examined changes in the expression of panel cell-cycle-specific markers after $48 \mathrm{~h}$. The mRNA concentration as well as the protein level of cyclin-D1 which functions in the transition from $\mathrm{G} 1$ to $S$ phase of the cell cycle decreased (Figures 5A and 5B). The mRNA concentration and the protein level of cyclin-A2, which is involved in transition from $S$ to G2, did not change significantly (Figure $5 \mathrm{C}$ and 5D). Collectively, these data support the notion that inhibition of ER $\beta$ induces cell-cycle arrest at the G0/G1 phase in H1650 cells, which is consistent with flow cytometric analysis. The results obtained from A549 also shown the changes of cyclinD1 and cyclinA2 when the expression of ER $\beta$ was blocked (Figure $5 B$ ).

\section{P53 and P21 expression was involved in cell growth inhibition through ER $\beta$-mediated signaling}

Inhibition of $\operatorname{ER} \beta$ expression by anti-ER $\beta$ siRNA markedly increased P53 expression at both mRNA level and protein level in H1650 cells as well as A549 cells. The overexpression was completely induced by anti-ER $\beta$ siRNA but not by a scramble siRNA control (Figures 6A-6D). Furthermore, the cyclin-dependent kinase cyclin inhibitors gene, P21 mRNA concentration were also upregulated by inhibition of ER $\beta$ siRNA. These finding establish that inhibition of ER $\beta$ induced upregulation of P53 and P21 as a direct mediator of the growth-inhibitory response.

\section{Discussion}

It is well established that ERs play a major role in pathological processes of lung cancer, while the results remain inconsistent. Early studies detected for the presence of the classical ERa only, and then with the development of ER $\beta$ antibody, the expression of ER $\beta$ was also found in lung cancer [28-30]. Many studied have shown the expression of ER $\beta$ in majority of human NSCLC cell lines as well as primary
A

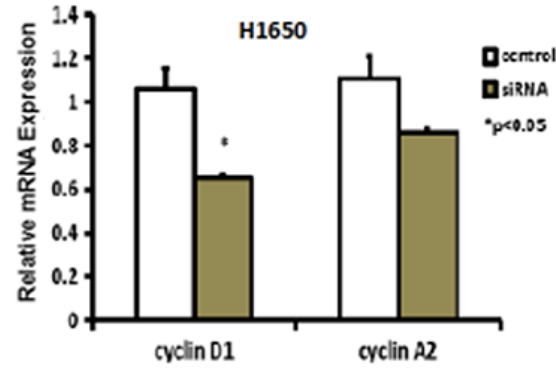

C

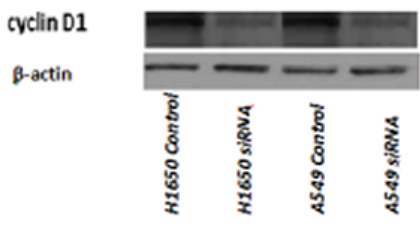

B

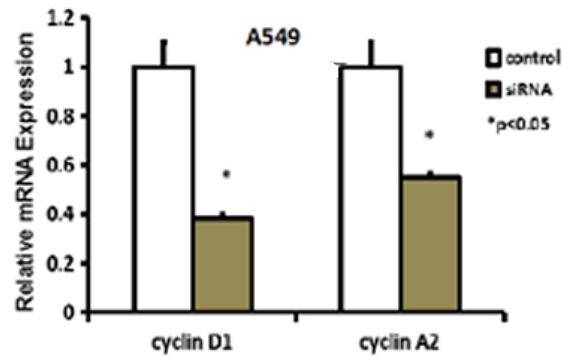

D

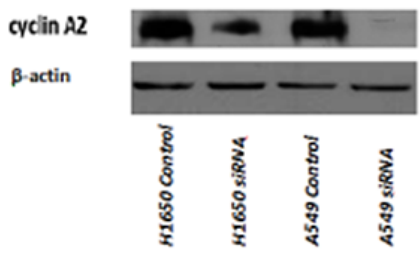

Figure 5: H1650 cells were subjected to real-time RT-PCR analysis to determine cylinD1 and cyclinA2 mRNA levels after ER 3 transfection for $48 \mathrm{~h}$. The mRNA expression of cyclinD1 was decreased significantly, while the mRNA expression of cyclinA2 had no difference, ${ }^{*} p<0.05$.

A

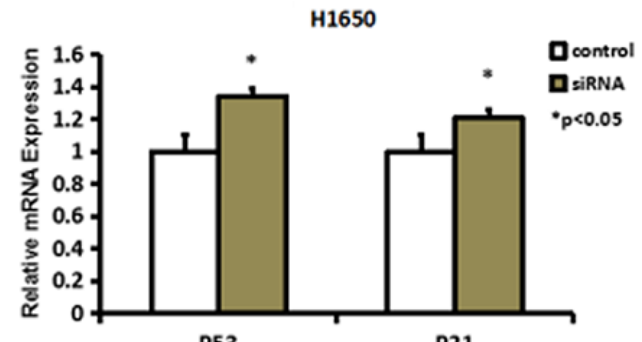

P53

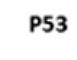

B-actin
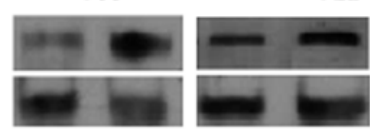

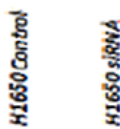

P21

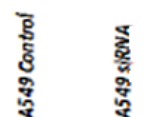

B
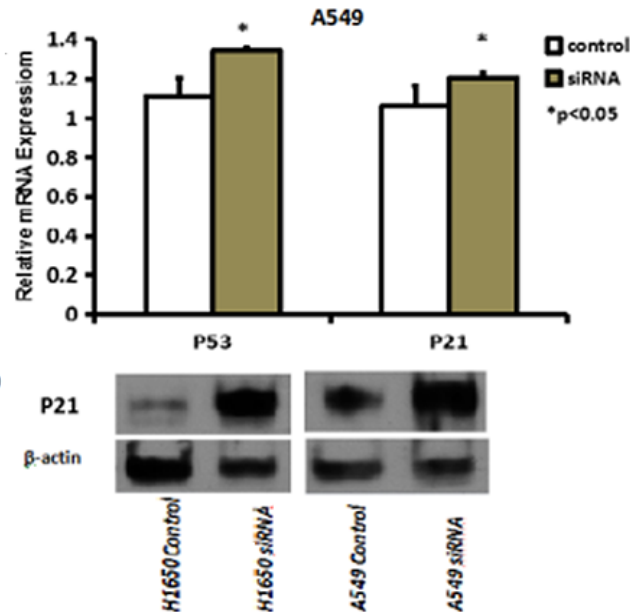

Figure 6: $\mathrm{H} 1650$ cells were subjected to real-time RT-PCR analysis to determine P53 and P21 mRNA levels after ER 3 transfection for $48 \mathrm{~h}$. The mRNA expression of both P53 and P21 were increased significantly after ER $\beta$ transfection. ${ }^{*} p<0.05,{ }^{* *} p<0.001$ 
tissues, however, the role of ERa in lung cancer is less clear, and also the relationship between ERs expression and tumor pathological stage, histology subtype and histologic grade are not clear. Our findings used NSCLC tissues and its corresponding tumor-free lung tissues to explore ERs expression in NSCLC, and the result is consistent with those in cell findings, which shown that both ERa and ER $\beta$ mRNA concentration of NSCLC tissues are higher than the corresponding normal lung tissues.

The other main question addressed in this study was whether expression of ERa or ER $\beta$ have relationships with tumor pathological stage, histology subtype or histologic grade. There is evidence suggests that in breast cancer, ERs is an important prognostic factor, which is the same case in lung cancer $[31,32]$. Our results showed that both $\mathrm{ERa}$ and ER $\beta$ were overexpressed in NSCLC tissues, and their mRNA concentration was related to the tumor pathological stage and histology subtype. Higher concentration of ERs mRNA has been found in T2 stage, and also that ERa and ER $\beta$ mRNA expression were higher in squamous carcinoma than in adenocarcinoma. In addition, evidence suggests that mRNA concentration of ERa was correlate with ER $\beta$, since we found that the number of patients who have either low level of ERa but high level of ER $\beta$ or high level of ERa but low level of ER $\beta$ were relatively small in present study.

In order to explain the activation of ERa and ER $\beta$ in the development of NSCLC separately, we selected a NSCLC cell line] which deprived from lung adenocarcinoma patients. Selected ERs specific siRNAs were successfully transfected into $\mathrm{H} 1650$ cell lines separately. ER $\beta$ but not ERa affects NSCLC cells proliferation. MTT method was used in this study for cell viability. The results showed that inhibitory ERs by selective siRNA or antagonist can block the cell proliferation induced by $10 \mathrm{nM} \mathrm{E2}$, however only the presence of ER $\beta$ but not ERa can accelerate cell growth. This is indicated that ER $\beta$ but not ERa was involved in cell proliferation. These results were consistent with other reports. A549 cells transfected with ER $\beta$ have increased proliferation in response to estrogen [33].

The progression of cells proliferation is associated with cell cycle, which is known to be positively regulated by a series of cyclin-dependent kinases (CDKs), as well as cyclins, and is negatively controlled by specific CDK inhibitors (CDKIs) [34-36]. CDKIs are separate into two classes, including this, the CIP/KIP family ((p21Waf1/Cip1, p27Kip1, and p57Kip2) which inhibits all CDKs by directly binding CDK complexes [37]. Wild-type P53 regulates cell transition from G1 to S phase in cell cycle and induce G1 arrest in response to DNA damage [38]. The $p 21 W a f 1 / C i p 1$ gene, which is transcriptional target of wildtype P53 $[39,40]$, is activated by wild-type P53 and is downstream effectors for P53 function by inducing G1 arrest if cells are exposed to DNA damaging agents [41]. We found that inhibitory of ER $\beta$ but not ERa by selective siRNA can leading to upregulation of P53 and $\mathrm{P} 21$, which in turn downregulated cyclinD1, which is G1-checkpoint regulator [42], and led to cell-cycle arrest at the G1 phase in $\mathrm{H} 1650$ cells. These findings provide credence for P21-mediation of ER $\beta$ -induced-cell cycle arrest at the G1 phase in H1650 cells.

One major limitation of the present study was small tissue samples. Therefore, it cannot be test the level of ERs protein in both lung cancer tissues as well as tumor free tissues. A further limitation was that a more detailed demonstration of the relationship between the level of GPR30 and lung cancer proliferation was not carried out. This was not completed because of the relatively low expression of GPR30 in lung cancer tissue. A further study with more detail on the correlation between GPR30 and lung cancer should be performed.

\section{Conclusion}

In conclusion, we showed that both ERa and ER $\beta$ play important role in development of NSCLC. ER $\beta$ were involved in proliferation of NSCLC induced by estrogen separately. The discovery of the expression pattern of ERs may open up an opportunity for development of estrogen-based therapy.

\section{References}

1. Ascenzi P, Bocedi A, Marino M (2006) Structure-function relationship of estrogen receptor alpha and beta: Impact on human health. Mol Aspects Med 27: 299-402

2. Pearce ST, Jordan VC (2004) The biological role of estrogen receptors alpha and beta in cancer. Crit Rev Oncol Hematol 50: 3-22.

3. Lin CY, Strom A, Li Kong S, Kietz S, Thomsen JS, et al. (2007) Inhibitory effects of estrogen receptor beta on specific hormone-responsive gene expression and association with disease outcome in primary breast cancer. Breast Cancer Res 9: 25

4. Behrens D, Gill JH, Fichtner I (2007) Loss of tumourigenicity of stably ERbetatransfected MCF-7 breast cancer cells. Mol Cell Endocrinol 274: 19-29.

5. Strom A, Hartman J, Foster JS, Kietz S, Wimalasena J, et al. (2004) Estrogen receptor beta inhibits 17beta-estradiol-stimulated proliferation of the breast cancer cell line T47D. Proc Natl Acad Sci USA 101: 1566-1571.

6. Zhao C, Matthews J, Tujague M, Wan J, Strom A, et al. (2007) Estrogen receptor beta2 negatively regulates the transactivation of estrogen receptor alpha in human breast cancer cells. Cancer Res 67: 3955-3962.

7. Treeck O, Pfeiler G, Mitter D, Lattrich C, Piendl G, et al. (2007) Estrogen receptor \{beta\}1 exerts antitumoral effects on SK-OV-3 ovarian cancer cells. J Endocrinol 193: 421-433.

8. Konduri S, Schwarz RE (2007) Estrogen receptor beta/alpha ratio predicts response of pancreatic cancer cells to estrogens and phytoestrogens. J Surg Res 140: 55-66

9. Satake K, Reber HA, Hines OJ, Eibl G (2006) Estrogen receptors in pancreatic tumors. Pancreas 33: 119-127.

10. Carruba G (2007) Estrogen and prostate cancer: An eclipsed truth in an androgen-dominated scenario. J Cell Biochem 102: 899-911.

11. Ricke WA, McPherson SJ, Bianco JJ, Cunha GR, Wang Y, et al. (2008) Prostatic hormonal carcinogenesis is mediated by in situ estrogen production and estrogen receptor alpha signaling. FASEB J 22: 1512-1520.

12. Kawabata W, Suzuki T, Moriya T, Fujimori K, Naganuma H, et al. (2003)Estrogen receptors (alpha and beta) and 17beta-hydroxy steroid dehydrogenase type 1 and 2 in thyroid disorders: possible in situ estrogen synthesis and actions. Mod Pathol 16: 437-444.

13. Zeng Q, Chen GG, Vlantis AC, van Hasselt CA (2007) Estrogen mediates the growth of human thyroid carcinoma cells via an estrogen receptor-ERK pathway. Cell Prolif 40: 921-935.

14. Zeng Q, Chen GG, Vlantis AC, Tse GM, van Hasselt CA (2008) Different contributions of estrogen receptor risoforms to the development of thyroid papillary and anaplastic cancers. J Pathol 214: 425-433.

15. Cho MA, Lee MK, Nam KH, ChungWY, Park CS, et al. (2007) Expression and role of estrogen receptor alpha and beta in medullary thyroid carcinoma: Different roles in cancer growth and apoptosis. J Endocrinol 195: 255-263.

16. Wang AG, Lee KY, Kim SY, Choi JY, Lee KH, et al. (2006) The expression of estrogen receptors in hepatocellular carcinoma in Korean patients. Yonsei Med J 47: 811-816

17. Villa E, Moles A, Ferretti I, Buttafoco P (2000) Grottola a natural history of inoperable hepatocellular carcinoma: Estrogen receptors' status in the tumor is the strongest prognostic factor for survival. Hepatology 32: 233-238.

18. Satake M, Sawai H, Go VL, Satake K, Reber HA, et al. (2006) Estrogen receptors in pancreatic tumors. Pancreas 33: 119-127.

19. Pietras RJ, Marquez DC, Chen HW, Tsai E, Weinberg O, et al. (2005) Estrogen and growth factor receptor interactions in human breast and non-small cell lung cancer cells. Steroids 70: 372-381. 
Citation: Yu N, Jia Y, Yu Y, Deng L, Shen C, et al. (2018) The Role of Estrogen Receptors in Proliferation of Non-Small Cell Lung Cancer. J Cancer Sci Ther 10: 045-051. doi:10.4172/1948-5956.1000516

20. Kawai H, Ishii A, Washiya K, Konno T, Kon H, et al. (2005) Combined overexpression of EGFR and estrogen receptor alpha correlates with a poor outcome in lung cancer. Anticancer Res 25: 4693-4698.

21. Kawai H, Ishii A, Washiya K, Konno T, Kon H, et al. (2005) Estrogen receptor alpha and beta are prognostic factors in non-small cell lung cancer. Clin Cancer Res 11: 5084-5089.

22. Schwartz AG, Prysak GM, Murphy V, Lonardo F (2005) Nuclear estrogen receptor beta in lung cancer: Expression and survival differences by sex. Clin Cancer Res 11: 7280-7287.

23. Prossnitz ER, Arterburn JB, Smith HO, Oprea TI, Sklar LA, et al. (2008) Estrogen signaling through the transmembrane $G$ protein-coupled receptor $G$ PR30. Annu Rev Physiol 70: 165-190.

24. Stabile LP, Siegfried JM (2004) Estrogen receptor pathways in lung cancer. Curr Oncol Rep 6: 259-267.

25. Marquez-Garban DC, Pietras RJ (2008) Estrogen-signaling pathways in lung cancer. Adv Exp Med Biol. 617:281-289.

26. Hershberger PA, Vasquez AC, Kanterewicz B, Land S, Siegfried JM, et al. (2005) Regulation of endogenous gene expression in human non-small cell lung cancer cells by estrogen receptor ligands.Cancer Res 65:1598-1605.

27. Stabile LP, Dacic S, Land SR, Lenzner DE, Dhir R, et al. (2011) Combined analysis of estrogen receptor beta-1 and progesterone receptor expression identifies lung cancer patients with poor outcome. Clin Cancer Res 17:154-164.

28. Stabile LP, Davis AL, Gubish CT, Hopkins TM, Luketich JD, et al. (2002) Human non-small cell lung tumors and cells derived from normal lung express both estrogen receptor alpha and beta and show biological responses to estrogen. Cancer Res 62: 2141-2150.

29. Wu CT, Chang YL, Shih JY, Lee YC (2005) The significance of estrogen receptor beta in surgically treated non-small cell lung cancers. J Thorac Cardiovasc Surg 130: 979-986.

30. Skov BG, Fischer BM, Pappot H (2008) Oestrogen receptor b over expression in males with non-small cell lung cancer is associated with better survival. Lung Cancer 59: 88-94.
31. Osborne CK, Yochmowitz MG, Knight WA, McGuire WL (1980) The value of estrogen and progesterone receptors in the treatment of breast cancer. Cancer 46: $2884-2888$

32. Thorpe SM, Rose C, Rasmussen BB, Mouridsen HT, Bayer T, et al. (1987) Prognostic value of steroid hormone receptors: multivariate analysis of systemically untreated patients with node negative primary breast cancer. Cancer Res 47: 6126-6133.

33. Niikawa H, Suzuki T, Miki Y, Suzuki S, Nagasaki S, et al. (2008) Intra tumora estrogens and estrogen 521 receptors in human non-small cell lung carcinoma Clin Cancer Res 522: 4417-4426.

34. Sherr CJ (1996) Cancer cell cycles. Science 274: 1672-1677.

35. Sherr CJ, Roberts JM (1995) Inhibitors of mammalian G1 cyclin-dependent kinases. Genes Dev 9: 1149-1163.

36. Steeg PS, Abrams JS (1997) Cancer prognostics: past, present and p27. Nat Med 3:152-154.

37. Hall M, Bates S, Peters G (1995) Evidence for different modes of action of cyclin-dependent kinase inhibitors: p15 and p16 bind to kinases, p21 and p27 bind to cyclins. Oncogene 11: 211-219.

38. Fu CG, Tominaga O, Nagawa H, Nita ME, Masaki T, et al. (1998) Role of p53 and $\mathrm{p} 21 / \mathrm{WAF} 1$ detection in patient selection for preoperative radiotherapy in rectal cancer patients. Dis Colon Rectum 41: 68-74

39. Harper JW, Adami GR, Wie N, Keyomarsi K, Elledge SJ (1993) The p21 cdkinteracting protein $\mathrm{Cip} 1$ is a potent inhibitor of $\mathrm{G} 1$ cyclin-dependent kinases. Cell 75: 805-816

40. Xiong Y, Hannon GJ, Zang H, Casso D, Kobayashi R (1993) p21 is a universa inhibitor of cyclin kinases. Nature 366: 701-704.

41. Brugarolas J, Chandrasekaran C, Gordor JI, Beach D, Jacks T, et al. (1995) Radiation-induced cell cycle arrest compromised by p21 deficiency. Nature 377: 552-557.

42. Bates S, Peters G (1995) Cyclin D1 as a cellular proto-oncogene. Semin Cancer Biol 6: 73-82. 